\title{
Silicon-containing diorganotin complexes with salicylaldehyde thiosemicarbazone and their anticancer activity
}

\author{
QIAN LIU, BO XIE, SEN LIN*® ${ }^{*}$, QIHUA LIAO, RUIHONG DENG and YAN ZHAOHUA* \\ Department of Chemistry, Nanchang University, Nanchang 330031, People's Republic of China \\ E-mail: senlin@ncu.edu.cn; yanzh@ncu.edu.cn
}

MS received 8 March 2019; revised 13 May 2019; accepted 24 May 2019

\begin{abstract}
Eight novel silicon-containing diorganotin complexes with salicylaldehyde thiosemicarbazone were synthesized. They were characterized by ${ }^{1} \mathrm{H}$ NMR, ${ }^{13} \mathrm{C}$ NMR, IR spectra, elemental analysis and X-ray singlecrystal diffraction. Spectroscopic and X-rays studies indicated that the thiosemicarbazone Schiff base and tin atom were coordinated as a parallel five- and six-membered heterocyclic structure. In addition, the bioassay of the synthesized complexes was performed and the results show that the silicon-containing diorganotin complexes with salicylaldehyde thiosemicarbazone have good anticancer activity on human breast cancer cells.
\end{abstract}

Keywords. Diorganotin; synthesis; structure; anticancer activity.

\section{Introduction}

Organotin compounds have been widely used in fields like industry, agriculture and others and the research on their bioactivities was getting more attention. ${ }^{1-5}$ Schiff base ligands are widely favored in the synthesis of metal compounds due to their mild synthesis condition and good biological activity. ${ }^{6-8}$ As a kind of Schiff base, the structure of salicylaldehyde thiosemicarbazone compounds contains the basic unit of activity $=\mathrm{N}(1) \mathrm{NH}(\mathrm{C}=\mathrm{S}) \mathrm{N}(4) \mathrm{H}-$, and the biological activity changes with the change of the group on $\mathrm{N}(1)$, which makes them have rich structural characteristics and antibacterial activity. ${ }^{9-12}$ A series of complexes synthesized by zinc(II) with 5-nitro-salicylaldehyde$\mathrm{N}$-substituted thiosemicarbazones were characterized and showed that these zinc(II) complexes have significant antimicrobial activity against Staphylococcus aureus, Salmonella typhimurium and Candida albicans. ${ }^{13}$ Elena Pahontuh combined thirty-two new complexes of $\mathrm{Cu}(\mathrm{II}), \mathrm{Ni}$ (II) and $\mathrm{Zn}$ (II) and salicylaldehyde thiosemicarbazone, the results indicated that most ligands and metal complexes showed significant selective and biological activity of Human Leukemia HL60 Cells in the antimicrobial or antifungal activity tests. ${ }^{14}$ Diorganotin compounds also have outstanding anti-tumor properties, but toxicity limits their development in medicine. ${ }^{15}$ In agricultural applications, the introduction of silicon can effectively reduce the toxicity of metals, and the presence of $\mathrm{Si}$ atoms can often reduce the toxicity and increase the activity of compounds. ${ }^{16,17}$ So we tried to investigate the effect of the introduction of silicon atoms on the biological activity of organotin complexes. On this basis, a series of new silicon-containing diorganotin complexes with salicylaldehyde thiosemicarbazone were designed and synthesized, and their biological activities were tested. The target complexes were characterized by ${ }^{1} \mathrm{H}$ NMR, ${ }^{13} \mathrm{C}$ NMR, IR spectra, elemental analysis and X-ray single-crystal diffraction.

\section{Experimental}

\subsection{Instruments and reagents}

The solvents used in the reaction are all commercially available analytical reagents, in which methanol is treated as an anhydrous solvent, and other solvents are used without further treatment. The intermediate containing silicon dihydrocarbyltin dichloride is synthesized by the reference method. ${ }^{18}$ The ligand reference is synthesized by N(4)-phenyl thiosemi-

\footnotetext{
*For correspondence

Electronic supplementary material: The online version of this article (https://doi.org/10.1007/s12039-019-1650-5) contains supplementary material, which is available to authorized users.
} 
carbazide and substituted salicylaldehyde, ${ }^{17}$ recrystallized with absolute ethanol.

The instruments are Bruker Avance 400 nuclear magnetic resonance $\left(\mathrm{CDCl}_{3}, \mathrm{TMS}\right)$, Vario EL III organic element analyzer; Guilin Optical instrument Factory X-5 melting Point measuring instrument (temperature uncorrected), Nicolet 460 FT infrared spectrometer) (KBr compression), Bruker APEXII CCD X-ray single Crystal diffractometer).

\subsection{Synthesis and determination of target products}

2.2a Synthesis of complexes: 3aa: Adding salicylaldehyde N(4)-phenylaminosulfur $0.272 \mathrm{~g} \mathrm{(1} \mathrm{mmol)} \mathrm{into} \mathrm{a} 100$ $\mathrm{mL}$ three-neck flask, charging an upper reflux condenser tube and a $25 \mathrm{~mL}$ drop liquid funnel, adding $30 \mathrm{~mL}$ of anhydrous methanol, and slightly heating to dissolve, adding $15 \mathrm{~mL}$ of a methanol solution containing $0.17 \mathrm{~g}(2 \mathrm{mmol})$ of sodium ethoxide under stirring, the reaction continues for $2 \mathrm{~h}$, then adding $\mathrm{Ph}\left(\mathrm{Me}_{3} \mathrm{SiCH}_{2}\right) \mathrm{SnCl}_{2} 3.54 \mathrm{~g}(1 \mathrm{mmol})$ of anhydrous methanol solution $(10 \mathrm{~mL})$, continuing to heat and reflux for $8 \mathrm{~h}$, cooling overnight, and filtering to obtain a dry solvent; filtering the filtrate while hot extracting with $30 \mathrm{~mL}$ of anhydrous n-hexane, cooling the filtrate, filtering to obtain a bright yellow powdery substance, $700 \mathrm{mg}$, and a yield of $63.6 \%$, M.p. 105.6 107.0 ${ }^{\circ} \mathrm{C}$. FT-IR (KBr) v: $3274,3134,3046,1600$, 1503, 1435, 1292, 1316, 1251, 1064, 837,755, 589, 519, 451. ${ }^{1} \mathrm{H}$ NMR $\left(400 \mathrm{MHz}, \mathrm{CDCl}_{3}\right) \delta 8.64(\mathrm{~s}, 1 \mathrm{H}, \mathrm{PhNH}), 7.86(\mathrm{~d}$, $J=7.1 \mathrm{~Hz}, 2 \mathrm{H}, \mathrm{ArH}), 7.54(\mathrm{~d}, J=7.8 \mathrm{~Hz}, 2 \mathrm{H}, \mathrm{ArH})$, $7.30 \sim 7.37(\mathrm{~m}, 6 \mathrm{H}, \mathrm{ArH}), 7.13(\mathrm{~d}, J=7.5 \mathrm{~Hz}, 1 \mathrm{H}, \mathrm{ArH})$, $7.06(\mathrm{t}, J=7.2 \mathrm{~Hz}, 1 \mathrm{H}, \operatorname{ArH}), 6.92(\mathrm{~d}, J=8.5 \mathrm{~Hz}, 1 \mathrm{H}$, $\mathrm{ArH}), 6.72\left(\mathrm{t}, J=7.3 \mathrm{~Hz}, 1 \mathrm{H}, \mathrm{ArH}_{\mathrm{r}}\right), 6.67(\mathrm{~s}, 1 \mathrm{H}, \mathrm{ArH})$, $0.78\left(\mathrm{~d}, J=12.4 \mathrm{~Hz}, 1 \mathrm{H}, \mathrm{SnCH}_{2}\right), 0.71(\mathrm{~d}, J=12.5 \mathrm{~Hz}$, $\left.1 \mathrm{H}, \mathrm{SnCH}_{2}\right), 0.05\left(\mathrm{~s}, 9 \mathrm{H}, \mathrm{SiCH}_{3}\right) .{ }^{13} \mathrm{C} \mathrm{NMR}(100 \mathrm{MHz}$, $\left.\mathrm{CDCl}_{3}\right) \delta 166.59\left(\mathrm{C}^{8}\right), 162.93\left(\mathrm{C}^{7}\right), 162.42\left(\mathrm{C}^{2}\right), 143.31$ $\left(C^{15}\right), 139.29\left(C^{9}\right), 135.73\left(C^{16,20}\right), 135.11\left(C^{6}\right), 133.93\left(C^{4}\right)$, $129.85\left(\mathrm{C}^{11,13}\right), 128.87\left(\mathrm{C}^{18}\right), 128.60\left(\mathrm{C}^{17,19}\right), 123.30\left(\mathrm{C}^{12}\right)$, $121.72\left(\mathrm{C}^{5}\right), 120.57\left(\mathrm{C}^{10,14}\right), 117.21\left(\mathrm{C}^{3}\right), 116.76\left(\mathrm{C}^{1}\right), 12.67$ $\left(\mathrm{SnCH}_{2}\right), 1.17\left(\mathrm{SiCH}_{3}\right)$. Anal. calcd for $\mathrm{C}_{24} \mathrm{H}_{27} \mathrm{~N}_{3} \mathrm{OSSiSn}$ : C 52.19, H 4.93, N 7.61; found: C 52.27, H 4.99, N 7.52.

3ab-3db obtained by using similar synthetic method.

3ab: $780 \mathrm{mg}$, bright yellow powder, and a yield of $69.0 \%$, M.p. $100.6 \sim 102.1^{\circ} \mathrm{C}$. FT-IR (KBr) v: $3274,3131,3045,1594$, $1504,1288,1317,1250,1059,823,591,500,450 .{ }^{1} \mathrm{H}$ NMR $\left(400 \mathrm{MHz}, \mathrm{CDCl}_{3}\right) \delta 8.63(\mathrm{~s}, 1 \mathrm{H}, \mathrm{PhNH}), 7.85 \sim 7.87(\mathrm{~m}, 2 \mathrm{H}$, $\operatorname{ArH}), 7.54(\mathrm{~d}, J=7.9 \mathrm{~Hz}, 2 \mathrm{H}, \mathrm{ArH}), 7.30 \sim 7.38(\mathrm{~m}, 6 \mathrm{H}$, ArH), $7.13(\mathrm{~d}, J=7.6 \mathrm{~Hz}, 1 \mathrm{H}, \operatorname{ArH}), 7.06(\mathrm{t}, J=7.4 \mathrm{~Hz}$, $1 \mathrm{H}, \mathrm{ArH}), 6.92(\mathrm{~d}, J=8.4 \mathrm{~Hz}, 1 \mathrm{H}, \mathrm{ArH}), 6.68 \sim 6.74(\mathrm{~m}, 2 \mathrm{H}$, $\mathrm{ArH}), 0.88\left(\mathrm{t}, J=7.9 \mathrm{~Hz}, 3 \mathrm{H}, \mathrm{CH}_{3}\right), 0.73(\mathrm{~d}, J=12.6 \mathrm{~Hz}$, $\left.2 \mathrm{H}, \mathrm{SnCH}_{2}\right), 0.49$ (d, $\left.J=7.8 \mathrm{~Hz}, 2 \mathrm{H}, \mathrm{SiCH}_{2}\right), 0.01(\mathrm{~s}, 6 \mathrm{H}$, $\left.\mathrm{SiCH}_{3}\right) .{ }^{13} \mathrm{C}$ NMR $\left(100 \mathrm{MHz}, \mathrm{CDCl}_{3}\right) \delta 166.65\left(\mathrm{C}^{8}\right), 162.93$ $\left(C^{7}\right), 162.42\left(C^{2}\right), 143.43\left(C^{15}\right), 139.38\left(C^{9}\right), 135.73\left(C^{16,20}\right)$, $135.10\left(C^{6}\right), 133.93\left(C^{4}\right), 129.85\left(C^{11,13}\right), 128.86\left(C^{18}\right)$, $128.59\left(\mathrm{C}^{17,19}\right), 123.29\left(\mathrm{C}^{12}\right), 121.71\left(\mathrm{C}^{5}\right), 120.57\left(\mathrm{C}^{10,14}\right)$, $117.20\left(\mathrm{C}^{3}\right), 116.87\left(\mathrm{C}^{1}\right), 10.79\left(\mathrm{SnCH}_{2}\right), 9.33\left(\mathrm{SiCH}_{2}\right), 7.36$ $\left(\mathrm{CH}_{3}\right),-1.17\left(\mathrm{SiCH}_{3}\right)$. Anal. Calcd for $\mathrm{C}_{25} \mathrm{H}_{29} \mathrm{~N}_{3} \mathrm{OSSiSn}$ : C 53.02, H 5.16, N 7.42; found: C 53.11, H 5.22, N 7.37. 3ba: $430 \mathrm{mg}$, yellow powder, and a yield of $74.1 \%$, M.p. $129.8 \sim 131.5{ }^{\circ} \mathrm{C}$. FT-IR (KBr) v: 3287, 1586, 1503, 1429, 1211, 1312, 731, 1246, 1080, 831, 597, 504, 421. ${ }^{1} \mathrm{H}$ NMR $\left(400 \mathrm{MHz}, \mathrm{CDCl}_{3}\right) \delta 8.63(\mathrm{~s}, 1 \mathrm{H}, \mathrm{PhNH}), 7.91 \sim 7.93(\mathrm{~m}, 2 \mathrm{H}$, $\mathrm{ArH}), 7.55(\mathrm{~d}, J=7.8 \mathrm{~Hz}, 2 \mathrm{H}, \mathrm{ArH}), 7.30 \sim 7.39(\mathrm{~m}$, $5 \mathrm{H}, \mathrm{ArH}), 7.06(\mathrm{t}, J=7.4 \mathrm{~Hz}, 1 \mathrm{H}), 6.91 \sim 6.96(\mathrm{~m}, 1 \mathrm{H})$, $6.75 \sim 6.77(\mathrm{~m}, 2 \mathrm{H}, \mathrm{ArH}), 6.66(\mathrm{t}, J=7.8 \mathrm{~Hz}, 1 \mathrm{H}), 3.91$ (s, $\left.3 \mathrm{H}, \mathrm{OCH}_{3}\right), 0.84\left(\mathrm{~d}, J=12.6 \mathrm{~Hz}, 1 \mathrm{H}, \mathrm{SnCH}_{2}\right), 0.77(\mathrm{~d}$, $\left.J=12.6 \mathrm{~Hz}, 1 \mathrm{H}, \mathrm{SnCH}_{2}\right), 0.05\left(\mathrm{~s}, 9 \mathrm{H}, \mathrm{SiCH}_{3}\right) .{ }^{13} \mathrm{C} \mathrm{NMR}$ $\left(100 \mathrm{MHz}, \mathrm{CDCl}_{3}\right) \delta 162.98\left(\mathrm{C}^{8}\right), 162.63\left(\mathrm{C}^{7}\right), 157.42\left(\mathrm{C}^{3}\right)$, $151.69\left(C^{2}\right), 143.19\left(C^{15}\right), 139.56\left(C^{9}\right), 136.01\left(C^{16,20}\right)$, $130.01\left(\mathrm{C}^{11,13}\right), 128.89\left(\mathrm{C}^{18}\right), 128.70 \sim 127.96\left(\mathrm{C}^{17,19}\right)$, $125.55\left(\mathrm{C}^{12}\right), 123.43\left(\mathrm{C}^{6}\right), 120.74\left(\mathrm{C}^{5}\right), 117.11\left(\mathrm{C}^{10,14}\right)$, $116.74\left(\mathrm{C}^{4}\right), 116.19\left(\mathrm{C}^{1}\right), 56.50\left(\mathrm{OCH}_{3}\right), 12.68\left(\mathrm{SnCH}_{2}\right)$, $1.24\left(\mathrm{SiCH}_{3}\right)$. Anal.Calcd for $\mathrm{C}_{25} \mathrm{H}_{29} \mathrm{~N}_{3} \mathrm{O}_{2} \mathrm{SSiSn}: \mathrm{C} 51.56$, H 5.02, N 7.10; found: C 51.70, H 5.09, N 7.14.

3bb: $480 \mathrm{mg}$, yellow powder, and a yield of $78.7 \%$, M.p. $105.8 \sim 107.4{ }^{\circ} \mathrm{C}$. FT-IR (KBr) v: 3316, 1586, 1503, 1429, 1209, 1318, 734, 1247, 1084, 831, 591, 508, 409. ${ }^{1} \mathrm{H}$ NMR $\left(400 \mathrm{MHz}, \mathrm{CDCl}_{3}\right) \delta 8.62(\mathrm{~s}, 1 \mathrm{H}, \mathrm{PhNH}), 7.87 \sim 7.95(\mathrm{~m}, 2 \mathrm{H}$, ArH), $7.54(\mathrm{~d}, J=7.7 \mathrm{~Hz}, 2 \mathrm{H}, \mathrm{ArH}), 7.30 \sim 7.38(\mathrm{~m}, 5 \mathrm{H}$, ArH), $7.06(\mathrm{t}, J=7.4 \mathrm{~Hz}, 1 \mathrm{H}), 6.90 \sim 6.96(\mathrm{~m}, 1 \mathrm{H}), 6.75$ $(\mathrm{d}, J=6.7 \mathrm{~Hz}, 1 \mathrm{H}), 6.63 \sim 6.69(\mathrm{~m}, 2 \mathrm{H}, \mathrm{ArH}), 3.90(\mathrm{~s}, 3 \mathrm{H}$, $\left.\mathrm{OCH}_{3}\right), 0.87\left(\mathrm{t}, J=7.9 \mathrm{~Hz}, 3 \mathrm{H}, \mathrm{CH}_{3}\right), 0.77(\mathrm{~d}, J=12.6 \mathrm{~Hz}$, $\left.2 \mathrm{H}, \mathrm{SnCH}_{2}\right), 0.49\left(\mathrm{~d}, J=8.1 \mathrm{~Hz}, 2 \mathrm{H}, \mathrm{SiCH}_{2}\right),-0.01 \sim 0.02$ $\left(\mathrm{m}, 6 \mathrm{H}, \mathrm{SiCH}_{3}\right) .{ }^{13} \mathrm{C} \mathrm{NMR}\left(100 \mathrm{MHz}, \mathrm{CDCl}_{3}\right) \delta 162.81$ $\left(\mathrm{C}^{8}\right), 162.48\left(\mathrm{C}^{7}\right), 157.22\left(\mathrm{C}^{3}\right), 151.54\left(\mathrm{C}^{2}\right), 143.06\left(\mathrm{C}^{15}\right)$, $139.41\left(C^{9}\right), 135.82\left(C^{16,20}\right), 129.83\left(C^{11,13}\right), 128.87\left(C^{18}\right)$, $128.58\left(\mathrm{C}^{17,19}\right), 125.37\left(\mathrm{C}^{12}\right), 123.27\left(\mathrm{C}^{6}\right), 120.53\left(\mathrm{C}^{5}\right)$, $116.95\left(\mathrm{C}^{10,14}\right), 116.58\left(\mathrm{C}^{4}\right), 116.01\left(\mathrm{C}^{1}\right), 56.38\left(\mathrm{OCH}_{3}\right)$, $10.67\left(\mathrm{SnCH}_{2}\right), 9.30\left(\mathrm{SiCH}_{2}\right), 7.34\left(\mathrm{CH}_{3}\right),-1.28\left(\mathrm{SiCH}_{3}\right)$. Anal. Calcd for $\mathrm{C}_{26} \mathrm{H}_{31} \mathrm{~N}_{3} \mathrm{O}_{2} \mathrm{SSiSn}$ : C 52.36, H 5.24, N7.05; found: C 52.58, H 5.33, N 6.98.

3ca: $310 \mathrm{mg}$, yellow powder and a yield of $51.7 \%$, M.p. $148.5 \sim 151.1{ }^{\circ} \mathrm{C}$. FT-IR (KBr) v: 3320, 1601, 1499, 1429, $1179,1318,752,1242,1097,831,591,504,421 .{ }^{1} \mathrm{H}$ NMR $\left(400 \mathrm{MHz}, \mathrm{CDCl}_{3}\right) \delta 8.68(\mathrm{~s}, 1 \mathrm{H}, \mathrm{PhNH}), 8.13 \sim 8.23(\mathrm{~m}, 2 \mathrm{H}$, ArH), $7.81 \sim 7.83(\mathrm{~m}, 2 \mathrm{H}, \mathrm{ArH}), 7.53(\mathrm{~d}, J=8.0 \mathrm{~Hz}, 2 \mathrm{H}$, ArH), $7.31 \sim 7.46(\mathrm{~m}, 5 \mathrm{H}, \mathrm{ArH}), 7.12(\mathrm{t}, J=7.4 \mathrm{~Hz}, 1 \mathrm{H}$, $\mathrm{ArH}), 6.92(\mathrm{~d}, J=9.2 \mathrm{~Hz}, 1 \mathrm{H}, \mathrm{ArH}), 6.84(\mathrm{~s}, 1 \mathrm{H}, \mathrm{ArH}), 0.87$ $\left(\mathrm{d}, J=12.5 \mathrm{~Hz}, 1 \mathrm{H}, \mathrm{SnCH}_{2}\right), 0.77(\mathrm{~d}, J=12.5 \mathrm{~Hz}, 1 \mathrm{H}$, $\left.\mathrm{SnCH}_{2}\right), 0.07\left(\mathrm{~s}, 9 \mathrm{H}, \mathrm{SiCH}_{3}\right) .{ }^{13} \mathrm{C} \mathrm{NMR}\left(100 \mathrm{MHz}, \mathrm{CDCl}_{3}\right) \delta$ $171.48\left(C^{2}\right), 164.22\left(C^{8}\right), 160.32\left(C^{7}\right), 142.21\left(C^{15}\right), 138.83$ $\left(C^{5}\right), 138.17\left(C^{9}\right), 135.83\left(C^{16,20}\right), 135.54\left(C^{11,13}\right), 130.68$ $\left(C^{4}\right), 130.36\left(C^{18}\right), 129.56\left(C^{17,19}\right), 128.94\left(C^{6}\right), 124.02$ $\left(\mathrm{C}^{12}\right), 122.20\left(\mathrm{C}^{10,14}\right), 121.07\left(\mathrm{C}^{3}\right), 116.03\left(\mathrm{C}^{1}\right), 13.25$ $\left(\mathrm{SnCH}_{2}\right), 1.17\left(\mathrm{SiCH}_{3}\right)$. Anal.Calcd for $\mathrm{C}_{24} \mathrm{H}_{26} \mathrm{~N}_{4} \mathrm{O}_{3} \mathrm{SSiSn}$ : C 48.26, H 4.39, N 9.38; found: C 48.26, H 4.51, 9.20.

3cb: $350 \mathrm{mg}$, yellow powder, a yield of $57.4 \%$, M.p. $146.5 \sim 151.5^{\circ} \mathrm{C}$. FT-IR (KBr) v: 3327, 1603, 1506, 1434, 1188, 1321, 752, 1246, 1097, 826, 591, 504, 421. ${ }^{1} \mathrm{H}$ NMR $\left(400 \mathrm{MHz}, \mathrm{CDCl}_{3}\right) \delta 8.68(\mathrm{~s}, 1 \mathrm{H}, \mathrm{PhNH}), 8.11 \sim 8.24(\mathrm{~m}, 2 \mathrm{H}$, ArH), $7.72 \sim 7.92(\mathrm{~m}, 2 \mathrm{H}, \operatorname{ArH}), 7.52(\mathrm{~d}, J=7.8 \mathrm{~Hz}, 2 \mathrm{H}$, ArH), $7.33 \sim 7.45(\mathrm{~m}, 5 \mathrm{H}, \mathrm{ArH}), 7.12(\mathrm{t}, J=7.3 \mathrm{~Hz}, 1 \mathrm{H}$, $\operatorname{ArH}), 6.92(\mathrm{~d}, J=9.2 \mathrm{~Hz}, 1 \mathrm{H}, \operatorname{ArH}), 6.84(\mathrm{~s}, 1 \mathrm{H}, \operatorname{ArH})$, $0.84 \sim 0.92\left(\mathrm{~m}, 4 \mathrm{H}, \mathrm{CH}_{3}, \mathrm{SnCH}_{2}\right), 0.75(\mathrm{~d}, J=12.5 \mathrm{~Hz}, 1 \mathrm{H}$, 
$\left.\mathrm{SnCH}_{2}\right), 0.51\left(\mathrm{~d}, J=8.1 \mathrm{~Hz}, 2 \mathrm{H}, \mathrm{SiCH}_{2}\right), 0.02(\mathrm{~d}, J=$

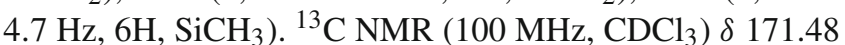
$\left(\mathrm{C}^{2}\right), 164.22\left(\mathrm{C}^{8}\right), 160.31\left(\mathrm{C}^{7}\right), 142.27\left(\mathrm{C}^{15}\right), 138.85\left(\mathrm{C}^{5}\right)$, $138.17\left(\mathrm{C}^{9}\right), 135.54\left(\mathrm{C}^{16,20}\right), 130.68\left(\mathrm{C}^{11,13}\right), 130.36\left(\mathrm{C}^{4}\right)$, $129.55\left(\mathrm{C}^{18}\right), 128.98\left(\mathrm{C}^{17,19}\right), 128.90\left(\mathrm{C}^{6}\right), 124.02\left(\mathrm{C}^{12}\right)$, $122.20\left(\mathrm{C}^{10,14}\right), 121.07\left(\mathrm{C}^{3}\right), 116.03\left(\mathrm{C}^{1}\right), 11.39\left(\mathrm{SnCH}_{2}\right)$, $9.30\left(\mathrm{SiCH}_{2}\right), 7.33\left(\mathrm{CH}_{3}\right),-1.14\left(\mathrm{SiCH}_{3}\right)$. Anal. Calcd for $\mathrm{C}_{24} \mathrm{H}_{32} \mathrm{~N}_{4} \mathrm{O}_{3} \mathrm{SSiSn}$ : C 49.11, H 4.62, N 9.16; found: C 48.99, $\mathrm{H} 4.73$, N 9.01 .

3da: $370 \mathrm{mg}$, bright yellow powder, and a yield of $63.8 \%$, M.p. $119.9 \sim 122.1{ }^{\circ} \mathrm{C}$. FT-IR (KBr) v: $3360 \nu(\mathrm{NH}) ; 1609$, 1515, 1435, 1216, 1314, 746, 1251, 1074, 833, 588, 516, 445. ${ }^{1} \mathrm{H} \mathrm{NMR}\left(400 \mathrm{MHz}, \mathrm{CDCl}_{3}\right) \delta 8.56(\mathrm{~s}, 1 \mathrm{H}, \mathrm{PhNH}), 7.88$ $(\mathrm{d}, J=6.6 \mathrm{~Hz}, 2 \mathrm{H}, \operatorname{ArH}), 7.53(\mathrm{~d}, J=8.3 \mathrm{~Hz}, 2 \mathrm{H}$, ArH), 7.37 7.41 (m, 3H, ArH), $7.30(\mathrm{t}, J=7.5 \mathrm{~Hz}, 2 \mathrm{H}$, ArH), $7.01 \sim 7.06(\mathrm{~m}, 2 \mathrm{H}, \mathrm{ArH}), 6.59(\mathrm{~d}, 1 \mathrm{H}, J=4.0 \mathrm{~Hz}$, $\mathrm{ArH}), 6.33 \sim 6.38(\mathrm{~m}, 2 \mathrm{H}, \mathrm{ArH}), 3.85\left(\mathrm{~s}, 3 \mathrm{H}, \mathrm{OCH}_{3}\right), 0.79$ $\left(\mathrm{d}, J=12.5 \mathrm{~Hz}, 1 \mathrm{H}, \mathrm{SnCH}_{2}\right), 0.70(\mathrm{~d}, J=12.5 \mathrm{~Hz}$, $\left.1 \mathrm{H}, \mathrm{SnCH}_{2}\right), 0.06\left(\mathrm{~d}, J=2.2 \mathrm{~Hz}, 9 \mathrm{H}, \mathrm{SiCH}_{3}\right) .{ }^{13} \mathrm{C} \mathrm{NMR}$ $\left(100 \mathrm{MHz}, \mathrm{CDCl}_{3}\right) \delta: 169.23\left(\mathrm{C}^{8}\right), 166.13\left(\mathrm{C}^{4}\right), 162.08\left(\mathrm{C}^{2}\right)$, $161.28\left(C^{7}\right), 143.59\left(C^{15}\right), 139.65\left(C^{9}\right), 135.74\left(C^{16,20}\right)$, $135.50\left(C^{6}\right), 129.80\left(C^{11,13}\right), 128.84\left(C^{18}\right), 128.59\left(C^{17,19}\right)$, $122.97\left(\mathrm{C}^{12}\right), 120.28\left(\mathrm{C}^{10,14}\right), 110.88\left(\mathrm{C}^{1}\right), 107.20\left(\mathrm{C}^{5}\right)$, $103.74\left(\mathrm{C}^{3}\right), 55.44\left(\mathrm{OCH}_{3}\right), 12.66\left(\mathrm{SnCH}_{2}\right), 1.21\left(\mathrm{SiCH}_{3}\right)$. Anal. Calcd for $\mathrm{C}_{25} \mathrm{H}_{29} \mathrm{~N}_{3} \mathrm{O}_{2} \mathrm{SSi}_{2} \mathrm{Sn}$ : C 51.56, H 5.02, N 7.22; found: C 51.09, H 5.07, N 6.93.

3db: $430 \mathrm{mg}$, bright yellow powder, and a yield of 70.3\%, M.p. $71.2 \sim 73.3^{\circ} \mathrm{C}$. FT-IR (KBr) v: 3379, 1609, 1511, 1433, 1216, 1311, 737, 1251, 1072, 824, 588, 501, 442. ${ }^{1} \mathrm{H}$ NMR $\left(400 \mathrm{MHz}, \mathrm{CDCl}_{3}\right) \delta 8.56(\mathrm{~s}, 1 \mathrm{H}, \mathrm{PhNH}), 7.86 \sim 7.88(\mathrm{~m}, 2 \mathrm{H}$, $\operatorname{ArH}), 7.53(\mathrm{~d}, J=8.3 \mathrm{~Hz}, 2 \mathrm{H}, \operatorname{ArH}), 7.36 \sim 7.41(\mathrm{~m}, 3 \mathrm{H}$, $\operatorname{ArH}), 7.31(\mathrm{t}, J=7.7 \mathrm{~Hz}, 2 \mathrm{H}, \operatorname{ArH}), 6.97 \sim 7.08(\mathrm{~m}, 2 \mathrm{H}$, ArH), 6.58 (s, 1H, ArH), 6.28 6.41 (m, 2H, ArH), 3.85 (s, 3H, $\left.\mathrm{OCH}_{3}\right), 0.89\left(\mathrm{t}, J=7.9 \mathrm{~Hz}, 3 \mathrm{H}, \mathrm{CH}_{3}\right), 0.76(\mathrm{~d}, J=12.5 \mathrm{~Hz}$, $\left.1 \mathrm{H}, \mathrm{SnCH}_{2}\right), 0.68\left(\mathrm{~d}, J=12.6 \mathrm{~Hz}, 1 \mathrm{H}, \mathrm{SnCH}_{2}\right), 0.50$ $\left(\mathrm{d}, J=7.7 \mathrm{~Hz}, 2 \mathrm{H}, \mathrm{SiCH}_{2}\right), 0.02(\mathrm{~d}, J=2.9 \mathrm{~Hz}, 6 \mathrm{H}$, $\left.\mathrm{SiCH}_{3}\right) .{ }^{13} \mathrm{C} \mathrm{NMR}\left(100 \mathrm{MHz}, \mathrm{CDCl}_{3}\right) \delta 169.22\left(\mathrm{C}^{8}\right), 166.12$ $\left(\mathrm{C}^{4}\right), 162.07\left(\mathrm{C}^{2}\right), 161.27\left(\mathrm{C}^{7}\right), 143.64\left(\mathrm{C}^{15}\right), 139.65\left(\mathrm{C}^{9}\right)$, $135.73\left(\mathrm{C}^{16,20}\right), 135.49\left(\mathrm{C}^{6}\right), 129.78\left(\mathrm{C}^{11,13}\right), 128.83\left(\mathrm{C}^{18}\right)$, $128.57\left(\mathrm{C}^{17,19}\right), 122.96\left(\mathrm{C}^{12}\right), 120.26\left(\mathrm{C}^{10,14}\right), 110.88\left(\mathrm{C}^{1}\right)$, $107.17\left(\mathrm{C}^{5}\right), 103.74\left(\mathrm{C}^{3}\right), 55.43\left(\mathrm{OCH}_{3}\right), 10.77\left(\mathrm{SnCH}_{2}\right)$, $9.36\left(\mathrm{SiCH}_{2}\right), 7.39\left(\mathrm{CH}_{3}\right),-1.15\left(\mathrm{SiCH}_{3}\right)$. Anal. Calcd for $\mathrm{C}_{26} \mathrm{H}_{31} \mathrm{~N}_{3} \mathrm{O}_{2} \mathrm{SSi}_{2} \mathrm{Sn}$ : C 52.36, H 5.24, N 7.05; found: $\mathrm{C}$ 51.72, H 5.29, N 6.83 .

2.2b Determination of crystal structure: The crystal suitable for single crystal diffraction was obtained by solvent volatilization method. The single crystal of complex 3ab and 3da of suitable size were selected and placed on the SMART-APEX II CCD diffractometer of Bruker Company. The scanning mode was $\omega / 2 \theta$ and the Mo-K $\alpha$ ray $(\lambda=0.71073 \AA)$ of graphite Monochromator was used as light source. At the temperature of $296(2) \mathrm{K}$, the diffraction data of complex $\mathbf{3 a b}$ and $\mathbf{3 d a}$ were collected, in the range of $2.50 \leq \theta \leq 25.50$ and $3.08 \leq \theta \leq 26.48$, all the diffraction points 19917 and 92228 are collected, and all the data are calculated on the computer by Bruker SHELXL-97 program, the crystal structure is solved by direct method. All the data were corrected by Lp factor and experiential absorption. All the non-hydrogen atom coordinates were determined successively in the subsequent differential Fourier synthesis, and the anisotropic parameters were modified by the full matrix twomultiplication method. The CCDC numbers of the complexes 3ab and 3da are 1022840 and 1040959.

2.2c Anticancer activity test: The antitumor activity of human MDA-MB-231 and MCF-7 breast cancer cell lines in vitro was tested by cell Counting $\mathrm{K}$ it-8 (CCK-8) assay. The inhibition rate of the sample on tumor cells was calculated indirectly by measuring the absorbance value (OD value) of the cell fluid in the culture medium. The test set up six concentration gradients of $500 \mathrm{mg} / \mathrm{L}, 100 \mathrm{mg} / \mathrm{L}, 50 \mathrm{mg} / \mathrm{L}, 25$ $\mathrm{mg} / \mathrm{L}, 12.5 \mathrm{mg} / \mathrm{L}, 6.25 \mathrm{mg} / \mathrm{L}$, and the steps were as follows: after inoculating $1.5 \times 10^{4}$ tumor cells in each hole of the 96 hole plastic culture plate, they were placed in an incubator $\left(37^{\circ} \mathrm{C}\right.$, concentration of carbon dioxide was $5 \%$ ). The tumor cells were attached to the wall. After $24 \mathrm{~h}$, the original culture medium was taken out, and the culture medium containing different concentration of DMSO solution was added. At the same time, the control group with various concentrations of DMSO solvent and the blank group with only medium were placed. After the plate was laid, the culture was continued in the incubator for $48 \mathrm{~h}$, and the first $4 \mathrm{~h}$ after incubation, $10 \mu \mathrm{L}$ of CCK-8 was added to each hole for $4 \mathrm{~h}$ after incubating in the incubator. The culture plate was quickly removed, the OD value of the medium was measured at the $450 \mathrm{~nm}$ wavelength by an enzyme marker, and the average value was calculated by the method of choice. The inhibition rate was calculated by the following formula:

Inhibition rate $(\%)=(\mathrm{OD}$ value of control group - OD value
of experimental group $) / O D$ value of control group $\times 100 \%$

\section{Results and Discussion}

\subsection{Synthesis}

N(4)-phenylthiosemicarbazide was synthesized by literature, ${ }^{18}$ and reacted with four silicon-containing dialkyltins to obtain eight target diorganotin complexes separately. Intermediate $\left(\mathrm{Me}_{3} \mathrm{SiCH}_{2}\right) \mathrm{PhSnCl}_{2}$ and $\left(\mathrm{Me}_{3} \mathrm{SiEtCH}_{2}\right) \mathrm{PhSnCl}_{2}$ were synthesized by literature. ${ }^{19}$ The synthetic method of organotin Schiff base chelates has been reported in the literature. ${ }^{20}$ In this paper, triethylamine was used as deprotonation agent to synthesize organotin Schiff base chelates, but the by-product triethylamine hydrochloride was difficult to remove, which made the obtained products impure. When sodium ethoxide was used as a base instead of triethylamine, satisfactory results were obtained. The reaction equation is as follows: 


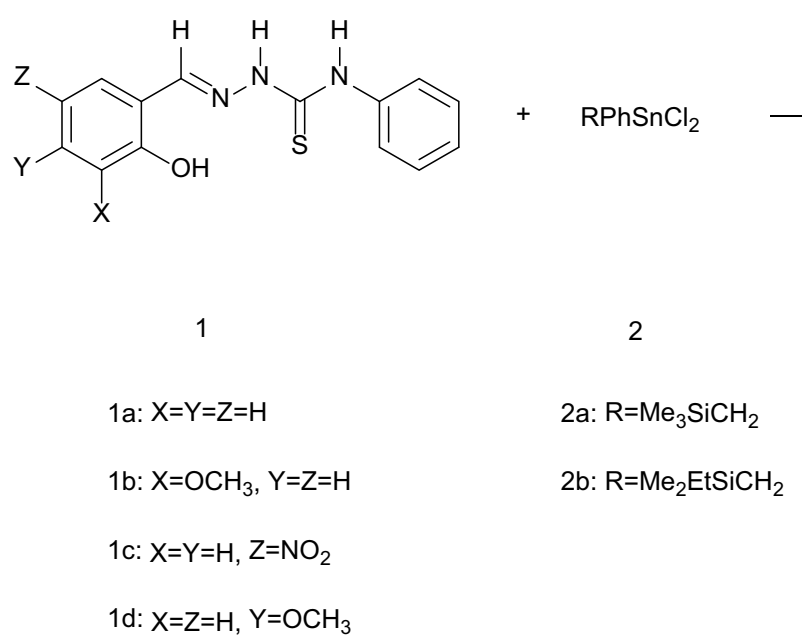

\subsection{Structural analysis}

The structure of the target product was preliminarily determined by IR, ${ }^{1} \mathrm{H}$ NMR and ${ }^{13} \mathrm{C}$ NMR spectra.

The IR spectra showed that no sharp bands of S$\mathrm{H}$ bond were found in $2700 \sim 2550 \mathrm{~cm}^{-1}$, indicating that the complexes may exist in the form of thioketom tautomers in the solid state. According to the related literatures, ${ }^{21,22}$ the absorption peaks at $1250 \sim 1247 \mathrm{~cm}^{-1}$ and $836 \sim 823 \mathrm{~cm}^{-1}$ belong to $\delta\left(\mathrm{SiCH}_{3}\right)$ and $\mathrm{v}(\mathrm{Si}-\mathrm{C})$, respectively. Comparing with the spectra of ligands, the spectra of target compounds showed that the v(O$\mathrm{H})$ absorption peak at $3200 \sim 3000 \mathrm{~cm}^{-1}$ in the ligands disappeared, and the $\mathrm{v}(\mathrm{C}-\mathrm{O})$ absorption peak at $1290 \sim 1250 \mathrm{~cm}^{-1}$ shifted to the low wavenumber direction after the formation of the complexes; $\mathrm{v}(\mathrm{Sn}-\mathrm{O})$ absorption peak appeared at $510 \sim 485 \mathrm{~cm}^{-1}$ in the complexes, which proved the formation of $\mathrm{Sn}-\mathrm{O}$ in the complexes. In addition, the absorption peaks of $\mathrm{v}(\mathrm{C}-\mathrm{S})$ at $1348 \sim 1320 \mathrm{~cm}^{-1}$ and $887 \sim 826 \mathrm{~cm}^{-1}$ in the ligands moved towards low wavenumber, which may be due to the formation of C-S single bond and tin atom by the ligands through tautomerism. The absorption peaks of $\mathrm{v}(\mathrm{N}-\mathrm{N})$ at $1075 \sim 1026 \mathrm{~cm}^{-1}$ in ligands were shifted to $1100 \sim 1033 \mathrm{~cm}^{-1}$, and the absorption peaks of $\mathrm{v}(\mathrm{Sn}-\mathrm{N})$ at $450 \sim 410 \mathrm{~cm}^{-1}$ indicated the formation of Sn-N bonds. Combined with the above data, the complexes were formed by the binding of the ligands with phenolic hydroxyl oxygen, imine nitrogen and sulfur of mercaptan with the central tin atom.

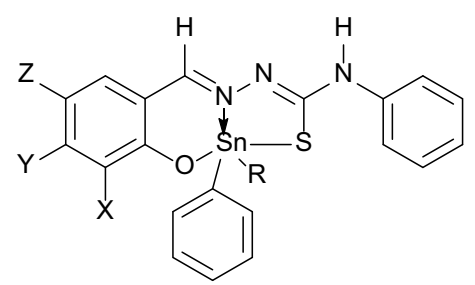

3

$$
\begin{aligned}
& \text { 3aa: } X=Y=Z=H, R=M_{3} \mathrm{SiCH}_{2} \\
& \text { 3ab: } X=Y=Z=H, R=M_{2} E_{\text {SICH}} \\
& \text { 3ba: } X=\mathrm{OCH}_{3}, Y=Z=H, R=\mathrm{Me}_{3} \mathrm{SiCH}_{2} \\
& \text { 3bb: } X=\mathrm{OCH}_{3}, Y=Z=H, R=\mathrm{Me}_{2} \mathrm{EtSiCH}_{2} \\
& \text { 3ca: } X=Y=H, Z=\mathrm{NO}_{2}, R=\mathrm{Me}_{3} \mathrm{SiCH}_{2} \\
& \text { 3cb: } X=Y=H, Z=\mathrm{NO}_{2}, R=\mathrm{Me}_{2} \mathrm{EtSiCH}_{2} \\
& \text { 3da: } X=Z=H, Y=\mathrm{OCH}_{3}, R=\mathrm{Me}_{3} \mathrm{SiCH}_{2} \\
& \text { 3db: } X=Z=H, Y=\mathrm{OCH}_{3}, R=\mathrm{Me}_{2} \mathrm{EtSiCH}_{2}
\end{aligned}
$$

From the ${ }^{1} \mathrm{H}$ NMR data of the complexes, it was observed that the signal of phenolic hydroxy hydrogen $(\delta 9.28 \sim 10.16)$ and hydrazine hydrogen $(\delta 11.62 \sim$ 11.67) disappeared after the formation of the complexes. It is shown that the ligands are coordinated with the central tin atom by two groups of phenolic hydroxyl oxygen and hydrazine group. The $\mathrm{PhN}-\mathrm{H}(\delta 10.1 \sim 11.6)$ signal in the ligands moved to the high field (88.54 9.49), which may be due to the disappearance of the hydrogen bond in the ligands after the formation of the complexes. The hydrogen signal of $\mathrm{CH}=\mathrm{N}$ in the ligands was transferred from $(\delta 8.37 \sim 9.15)$ to $(\delta 7.53 \sim 8.24)$ because the $\mathrm{N}$ atom of $\mathrm{CH}=\mathrm{N}$ coordinated with the central tin atom when the target compound was formed. Two hydrogen atoms in $\mathrm{SnCH}_{2}$ directly connected to a tin atom are coupled to form a quadruplex $(0.76 \sim 0.79$ and $0.69 \sim 0.72$, $J=12.5 \mathrm{~Hz}$ ) because of the central tin atoms combined with four different groups causing the two hydrogens to be located in a different environment.

In the ${ }^{13} \mathrm{C}$ NMR of ligands, the corollaries in IR and ${ }^{1} \mathrm{H}$ NMR were further verified. After the formation of the complex, the resonance signal of $\mathrm{NH}-\mathrm{C}=\mathrm{S}$ in the spectra of the ligands shifted from $175.68 \sim 176.14 \mathrm{ppm}$ to $162.04 \sim 168.79 \mathrm{ppm}$ in the complexes spectra, which can be considered as an $\mathrm{N}=\mathrm{C}-\mathrm{S}$ group and coordinated with the central tin atom. The resonance signal of $\mathrm{CH}=\mathrm{N}$ moves from $139.60 \sim 143.95 \mathrm{ppm}$ to low field to $160.31 \sim 162.93 \mathrm{ppm}$. This may be due to the coordination of $\mathrm{N}$ atom in $\mathrm{CH}=\mathrm{N}$ with the central tin atom, which reduces the electron cloud density of double bond in $\mathrm{CH}=\mathrm{N}$ and increases the chemical shift. 


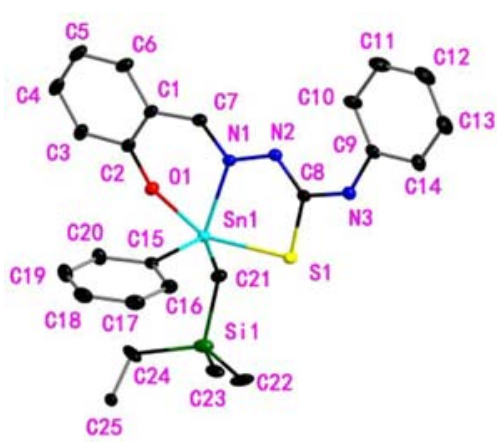

Figure 1. Complex 3ab.

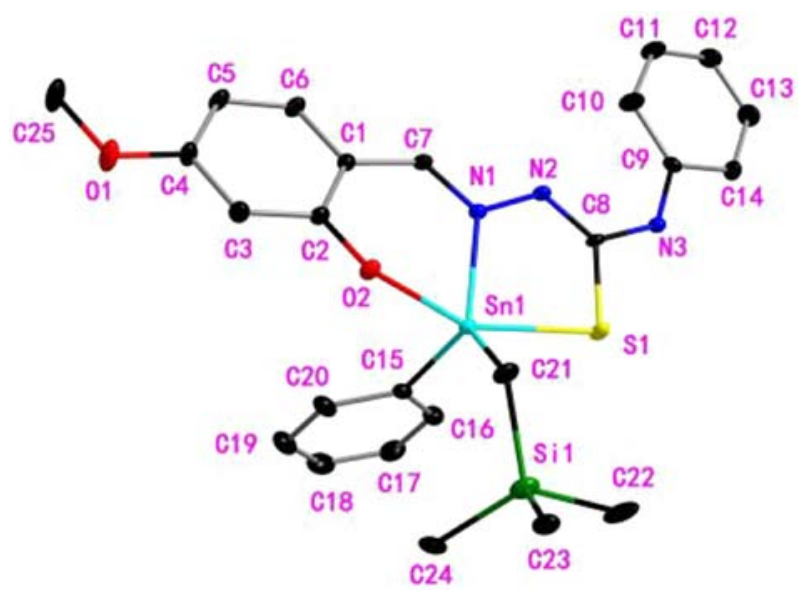

Figure 2. Complex 3da.

\subsection{Crystal structure}

The molecular structures of the complexes $\mathbf{3 a b}$ and 3da were determined by X-ray single-crystal diffraction. The crystal data and related materials are listed in the supporting materials Table S1 and S2 (Supplementary Information). The CCDC numbers are 1022840 and 1040959. The molecular structures of the complexes are shown in Figures 1 and 2.

From the X-ray diffraction analysis, it is found that the methyl carbon atom in a silicon hydrocarbyl group in the complex 3da has a disordered structure, which is due to the crystallographic parameters collected at room temperature.

By observing the molecular structure of 3ab and 3da, it was found that both of them were obtained by the reaction of salicylaldehyde acetal, thiourea and mixed dialkyltin dichloride containing silicon to form a pentagonal tin mononuclear center molecule, thus forming a distorted triangular bipyramidal geometry. While thiosemicarbazone Schiff base is used as a ligand to form five-member and six-member heterocyclic parallel structures through the coordination of oxygen, nitrogen, sulfur and tin atoms. In this paper, the structure of the complex $\mathbf{3 a b}$ is discussed as an example, in which two hydrocarbon groups in imine nitrogen and dialkyltin form the equatorial plane. However, the degree of the angle between phenol $\mathrm{O}$ and mercaptan $\mathrm{S}$ occupies its axial position. The axial angle of $\mathrm{O}(1)-\mathrm{Sn}(1)-\mathrm{S}(1)$ is $154.10(7)^{\circ}$, which indicates that the structure deviates from the ideal triangular bipyramidal geometry and is a twisted triangular bipyramidal geometry. $\mathrm{Sn}(1)$ and $\mathrm{N}(1), \mathrm{C}(15), \mathrm{C}(21)$ in the equatorial position is: $\mathrm{C}(15)-\mathrm{Sn}-(1)-\mathrm{C}(21) 124.19$ (14) $)^{\circ}$, respectively, $\mathrm{C}(15)-\mathrm{Sn}(1)-\mathrm{N}(1) 102.00$ (11) ${ }^{\circ}, \mathrm{C}(21)-$ $\mathrm{Sn}(1)-\mathrm{N}(1) 133.70(13)^{\circ}$, the sum of the triangles is $359.89^{\circ}$. Therefore, the axial angle of $\mathrm{Sn}(1)$ and $\mathrm{N}(1)$, C (15), C (21) are coplanar.

In the molecule of $\mathbf{3 a b}$, the distance of $\mathrm{Sn}-\mathrm{S}$ is 2.5229(11) $\AA$, which is close to the sum of covalent radius between $\mathrm{Sn}$ and $\mathrm{S}$ atoms, but is much smaller than that of van der wals radius $(4.0 \AA)$ between two atoms. This indicated that the complex formed a strong Sn$\mathrm{S}$ bond. The distance between $\mathrm{Sn}(1)-\mathrm{N}(1)$ is 2.219(3), $\mathrm{Sn}(1)-\mathrm{O}(1)$ is 2.103(2), which is very close to the sum of the covalent radius of $\mathrm{Sn}-\mathrm{N}(2.15 \AA)$ and $\mathrm{Sn}-\mathrm{O}(2.10 \AA)$. It is shown that the central tin atom has a strong interaction with phenolic $\mathrm{O}$ and imine. The bond length of $\mathrm{C}(8)-\mathrm{S}(1)$ bond increases from $1.680(2) \AA$ of the ligand to $1.741(3) \AA$. The distance between $\mathrm{C}(8)-\mathrm{N}(2)$ was

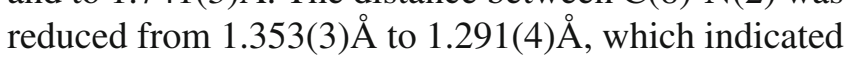
that the ligand formed a complex with tautomerism and electron delocalization of mercaptan and ketone. The C$\mathrm{S}$ bond is changed from double bond to a single bond, while $\mathrm{C}(8)-\mathrm{N}(2)$ becomes a double bond, which is consistent with the results of IR and NMR analysis.

Combined with infrared and nuclear magnetic resonance data, it can be inferred that other compounds also have similar structures.

\subsection{In vitro anticancer activity}

The antitumor activity against human MDA-MB-231 and MCF-7 breast cancer cell lines were tested by Cell Counting $\mathrm{K}$ it-8(CCK-8) method in vitro. The results are shown in Tables 1 and 2.

According to the above test data, in vitro activity test of human breast cancer cell MDA-MB-231, most of the complexes showed good biological activity, except for 3da in the range of 100-50 mg/L. The inhibition rates of the other complexes were above $96 \%$, and the activities of 3aa, 3ca and 3da decreased significantly when the concentration was reduced to $25 \mathrm{mg} / \mathrm{L}$. The inhibition rate of other complexes remained more than $93 \%$. When the concentration decreased to $12.5 \mathrm{mg} / \mathrm{L}$, the inhibition rate of $\mathbf{3 b b}$ remained more than $90 \%$. The inhibition rate of cisplatin was reduced to $29.93 \%$. In vitro activity test 
Table 1. In vitro antitumor activity of title complexes against MDA-MB-231.

\begin{tabular}{lccccc}
\hline \multirow{2}{*}{ Complex } & \multicolumn{5}{c}{ Inhibition rate\% } \\
\cline { 2 - 6 } & $100 \mathrm{mg} \cdot \mathrm{L}^{-1}$ & $50 \mathrm{mg} \cdot \mathrm{L}^{-1}$ & $25 \mathrm{mg} \cdot \mathrm{L}^{-1}$ & $12.5 \mathrm{mg} \cdot \mathrm{L}^{-1}$ & $6.25 \mathrm{mg} \cdot \mathrm{L}^{-1}$ \\
\hline 3aa & 97.41 & 96.32 & 54.43 & 52.92 & 43.29 \\
3ab & 96.99 & 97.28 & 94.47 & 36.60 & 30.36 \\
3ba & 98.28 & 97.19 & 96.73 & 93.14 & - \\
3bb & 99.82 & 98.13 & 97.21 & 86.93 & 12.73 \\
3ca & 98.72 & 97.55 & 64.63 & 22.61 & 4.33 \\
3cb & 98.32 & 96.97 & 96.77 & 69.25 & 18.93 \\
3da & 97.06 & 78.76 & 47.98 & 19.93 & 14.46 \\
3db & 99.74 & 97.44 & 93.15 & 31.34 & 11.12 \\
Cisplatin & 98.84 & 98.31 & 65.49 & 29.93 & 13.40 \\
\hline
\end{tabular}

Table 2. In vitro antitumor activity of title complexes against MCF-7.

\begin{tabular}{lccccc}
\hline \multirow{2}{*}{ Complex } & \multicolumn{5}{c}{ Inhibition rate\% } \\
\cline { 2 - 6 } & $100 \mathrm{mg} \cdot \mathrm{L}^{-1}$ & $50 \mathrm{mg} \cdot \mathrm{L}^{-1}$ & $25 \mathrm{mg} \cdot \mathrm{L}^{-1}$ & $12.5 \mathrm{mg} \cdot \mathrm{L}^{-1}$ & $6.25 \mathrm{mg} \cdot \mathrm{L}^{-1}$ \\
\hline 3aa & - & 20.83 & 12.32 & 54.62 & 45.75 \\
3ab & 85.41 & 87.75 & 80.97 & 28.25 & - \\
3ba & 96.64 & 92.72 & 45.33 & 13.68 & - \\
3bb & 97.54 & 95.19 & 87.68 & 32.19 & 17.58 \\
3ca & 98.33 & 90.31 & 65.19 & 21.01 & 22.19 \\
3cb & 95.14 & 92.97 & 78.11 & 33.02 & 30.76 \\
3da & 73.49 & 41.02 & 33.67 & 24.22 & 18.63 \\
3db & 93.49 & 58.94 & 48.74 & 28.62 & 26.17 \\
Cisplatin & 0.13 & 0.16 & 5.93 & 3.03 & - \\
\hline
\end{tabular}

of MCF-7, 3aa showed good activity at low concentration. When the concentration was $100-50 \mathrm{mg} / \mathrm{L}$, the inhibition rate of other complexes was more than $90 \%$ except for 3aa, 3ab and 3da, and the inhibition rate was more than $90 \%$ in all concentration ranges. The inhibition rate of the complexes was higher than that of cisplatin.

The thiourea complexes of salicylaldehydecondensed amino acids showed good inhibitory activity in vitro on both cell lines, and many of the complexes showed higher bioactivity than cisplatin, especially $\mathbf{3 b b}$ and $\mathbf{3 d b}$. In general, the activity of MDA-MB-231 in human breast cancer cells is stronger than that of MCF7.

Combining the inhibition rates of Tables 1 and 2, the $\mathrm{IC}_{50}$ values obtained according to the corresponding formula are shown in Tables 3 and 4.

Comparing the $\mathrm{IC}_{50}$ values of $1 \mathrm{aa}$ and $\mathbf{3 a b}, \mathbf{3 b a}$ and 3bb, 3ca and 3cb, 3da and 3db, it can be found that the latter is smaller than the former, that is, the latter has stronger activity against human breast cancer cells (MDA-MB-231 and MCF-7) than the former. This result indicates that small changes in hydrocarbon groups affect the anticancer activity of the complex, and the longer hydrocarbon chain gets better activity of
Table 3. $\mathrm{IC}_{50}$ value of title complexes against MDA-MB231(mg/L).

\begin{tabular}{lr}
\hline Complex & $\mathrm{IC}_{50}$ value \\
\hline 3aa & 8.05 \\
3ab & 6.73 \\
3ba & 9.75 \\
3bb & 7.26 \\
3ca & 18.57 \\
3cb & 5.70 \\
3da & 22.18 \\
3db & 11.90 \\
Cisplatin & 14.52 \\
\hline
\end{tabular}

the complex. Among them, the best anti-human breast cancer cell MDA-MB-231 activity is $\mathbf{3 c b}$, and its $\mathrm{IC}_{50}$ value is $5.70 \mathrm{mg} / \mathrm{L}$, and the $\mathrm{IC}_{50}$ value of cisplatin is $14.52 \mathrm{mg} / \mathrm{L}$, the best anti-human breast cancer cell MCF-7 activity is $\mathbf{3 a b}$, and its $\mathrm{IC}_{50}$ value is $7 \mathrm{mg} / \mathrm{L}$. At this time, the $\mathrm{IC}_{50}$ value of cisplatin is more than 100 $\mathrm{mg} / \mathrm{L}$. These results provide more possibilities for the research and development of metal anticancer drugs and provide some experimental data and theoretical guidance for the development and application of organotin 
Table 4. $\mathrm{IC}_{50}$ value of title complexes against MCF-7(mg/L).

\begin{tabular}{lr}
\hline Complex & $\mathrm{IC}_{50}$ value \\
\hline 3aa & 16.89 \\
3ab & 7.00 \\
3ba & 21.26 \\
3bb & 10.88 \\
3ca & 15.81 \\
3cb & 10.37 \\
3da & 35.66 \\
3db & 21.23 \\
Cisplatin & $>100$ \\
\hline
\end{tabular}

anticancer drugs. But their performance should be further studied.

\section{Conclusions}

Schiff base of salicylaldehyde amino acid thiourea was used as a ligand to react with dialkyltin dichloride. Thirteen complexes were obtained and characterized by IR and ${ }^{1} \mathrm{HNMR},{ }^{13} \mathrm{C}$ NMR, elemental analysis. The structure of the complex is further illustrated by X-ray single-crystal diffraction. The structure of the complex is a five-coordinate twisting triangular bipyramidal structure with the tin atom as the center. The anticancer activity of all the complexes was tested in vitro. The results showed that all the complexes exhibited better anticancer activity against MDA-MB-231 and MCF7 , overall, the biological activity of MDA-MB-231 is superior to that of MCF-7, and some of the complexes showed stronger activity than cisplatin. It provides good experimental data and theoretical guidance for the development and application of organotin complexes as anticancer drugs in the future, but its anticancer mechanism and other characteristics need to be further studied.

\section{Supplementary Information (SI)}

Tables S1.1-S2.1 is available at www.ias.ac.in/chemsci.

\section{References}

1. Yan X T, He B, Liu L H, Qu G B, Shi J B, Liao C Y, Hu L G and Jiang G B 2018 Organotin exposure stimulates steroidogenesis in H295R Cell via cAMP pathway Ecotox. Environ. Saf. 156148

2. Ransi D, Neil R E and Tilo S 2015 Organotin carboxylate catalyst in urethane formation in a polar solvent: an experimental and computational study $R S C A d v .5$ 48935

3. Muhammad M N and Klaus J 2017 Organotin-based receptors for anions and ion pairs Chem. Commun. 53 8122
4. Ali A and Adel N 2019 New organotin(IV) chlorides derived from $N$-(2-hydroxyphenyl) aryloxy sulfamates, Synthesis, characterization and DSC investigation $J$. Chem. Sci. 13112

5. Jerry O A and Damian C O 2018 Organotin(IV) dithiocarbamate complexes chemistry and biological activity Molecules 232571

6. Tahani I K 2017 Synthesis, characterization, biological and anticancer activity of new Pd(II), Pt(IV), V(III) and $\mathrm{Ru}(\mathrm{III})$ complexes with a schiff base ligind deriving from dehydroacetic acid J. Chem. Pharma. Res. 9164

7. Jai D and Suman D 2017 Synthesis, characterization and antimicrobial evaluation of schiff base complexes derived from [2,2'-(ethylenedioxy)bis(ethylamine)] and 5-chlorosalicylaldehyde Der. Pharma. Chem. 989

8. Jose M G, Teresa R A, Antonio N C, Simon H O and Elizabeth G 2017 Schiff base $\mathrm{Sn}(\mathrm{IV})$ complexes as cytotoxic agents: synthesis, structure, isosteric and bioisosreric replacement J. Organomet. Chem. 848332

9. Miljan N M, Aliona D, Ghenadie N, Nevenka G, Sinisa R, Jozef K, Peter R, Eva A E and Vladimir B A 2017 Effects of terminal substitution and iron coordination on antiproliferative activity of L-proline-salicylaldehydethiosemicarbazone hybrids Eur. J. Inorg. Chem. 40 4773

10. Nisha G, Anitta R T, Radhu S and Mary N L 2017 Plasmon-enhanced, two-photon absorption in Schiffbase-modified poly(styrene-co-maleic anhydride)-gold nanocomposites J. Appl. Polym. Sci. 13446

11. Wasinee P, Victor M, Casey G D, Guy N L, Boujemaa M and Keith S M 2016 Ligand effects in a heteroleptic bis-tridentate iron(III) spin crossover complex showing a very high $\mathrm{T}_{1 / 2}$ value Chem. Commun. 521443

12. Haque R A and Salam M A 2015 Synthesis, structural characterization and biological activities of organotin(IV) complexes with 5-allyl-2-hydroxy-3methoxybenzaldehyde-4- thiosemicarbazone J. Chem. Sci. 1271589

13. Shikha I, Tarlok S L, Henna S, Daljit S A, Geeta H and Jerry P J 2016 Synthesis, spectroscopy, structures and antimicrobial activity of mixed-ligind zinc(II) complexes of 5-nitro-salicylaldehyde thiosemicarbazones New J. Chem. 403642

14. Pahontu E, Fala V, Gulea A, Poirier D, Tapcov V and Rosu T 2013 Synthesis and characterization of some new $\mathrm{Cu}(\mathrm{II}), \mathrm{Ni}(\mathrm{II})$ and $\mathrm{Zn}(\mathrm{II})$ complexes with salicylidene thiosemicarbazones: antibacterial antifungal and in vitro antileukemia activity Molecules 188812

15. Niu L, Li Y L and Li Q S 2014 Medicinal properties of organotin compounds and their limitations caused by toxicity Inorg. Chim. Acta $\mathbf{4 2 3} 2$

16. Matichenkov V V, Bocharnikova E A, Pahnenko E P, Khomiakov D M, Matichenkov I V, Zhan Q and Wei X 2016 Reduction of $\mathrm{Cd}, \mathrm{Cu}, \mathrm{Ni}$, and $\mathrm{Pb}$ mobility by active $\mathrm{Si}$ in a laboratory study Mine Water Environ. 35302

17. Xie Q L, Sha G L and Liu Y L 1994 The Synthesis of [(phenyldimehtylsilyl) methyl] dicyelohexylitn dihtiophosphates Chin. J. Org. Chem. 14536

18. Kalaivani P, Prabhakaran R, Kaveri M V, Huang R, Staples R J and Natarajan K 2013 Synthesis, spectral, X-ray crystallography, electrochemistry, DNA/protein binding and radical scavenging activity of new palladium(II) 
complex containing triphenylarsine Inorg. Chim. Acta 405415

19. Lin S, Guo Y Y, Deng R H and Huang Z Q 2013 Catalytic activities of dialkytin compounds containing silicon to the condensation reaction of acetal(ketal)-alcohol Chin. J. Appl. Chem. 30271

20. Mala N and Pramendra K S 2011 Chemistry and applications of organotin(IV) complexes of schiff bases Dalton Trans. 407077
21. Lin S, Fu Z F, He X L, Liu H Y, Sun X Q, Wang X and Lu L D 2006 Synthesis, structure and anticancer activity of cyclohexyl (trimethysilylmethylene) tin diaromatase Chin. J. Org. Chem. 26856

22. Gong G F, Song R, Zou Y B and Lin S 2013 Synthesis, characterization and antitumour activity of diorganotin (IV) complexes containing cilicon of 2-mercaptobenzothiazole Chin. J. Org. Chem. 33 803 